DOI https://doi.org/10.30525/978-9934-26-173-2-6

\title{
ПРОБЛЕМИ ПІДРУЧНИКОТВОРЕННЯ ДЛЯ ЗДОБУВАЧІВ ОСВІТИ $З$ ПОРУШЕННЯМИ ЗОРУ В УКРАЇНІ
}

\author{
Серпутько Г. П. \\ кандидат філологічних наук, дочент, \\ докторант кафедри офтальмопедагогіки та офтальмопсихологіі \\ Національний педагогічний університет імені М. П. Драгоманова \\ Федоренко С. В. \\ доктор педагогічних наук, професор, \\ завідувач кафедри логопедї та логопсихології \\ Національний педагогічний університет імені М. П. Драгоманова \\ Федоренко М. I. \\ кандидат педагогічних наук, доцент, \\ дочент кафедри спеціальної психології та медицини \\ Національний педагогічний університет імені М. П. Драгоманова \\ м. Київ, Украӥна
}

Основоположні наукові засади теорії шкільного підручника, як галузі педагогічного дослідження, закладені ще у працях Я. Коменського, подальшого розвитку набули у вченні К. Ушинського, знайшли відображення у працях І. Лернера, В. Беспалька, Н. Буринської, Д. Зуєва, Ю. Бабанського. На сучасному етапі розвитку педагогічної науки проблемам історії, теорії і практики підручникотворення присвяченні грунтовні дослідження Я. Кодлюк, праці О. Савченко, М. Вашуленка, Н. Хребтової та ін.

У спеціальній педагогіці над дидактичними основами підручникотворення для дітей із порушеннями слуху та мовлення працювали М. Шеремет, Л. Фомічова, В. Котова, К. Луцько, Е. Данілавічютє, Ю. Рібцун тощо. Науково-методичні основи підготовки підручників для дітей з інтелектуальними порушеннями здійснювали: В. Бондар, В. Синьов, В. Турчинська, С. Миронова, Т. Сак, Л. Вавіна, Н. Кравець, В. Липа, Л. Одинченко. Теоретико-методологічні засади становлення й динаміки розвитку підручника для навчання школярів 3 інтелектуальними порушеннями грунтовно проаналізовані у дослідженні Л. Чепурної.

В українській тифлопедагогіці питаннями дидактичного наповнення, створення та адаптації підручників для дітей зі зниженим зором та незрячих учнів займалися науковці і практики: І. Моргуліс, Є. Синьова, 
Л. Вавіна, Н. Малюхова, С. Федоренко, С. Покутнєва, В. Ремажевська, К. Глушенко, Т. Гребенюк, І. Гудим, К. Довгопола, О. Набоченко та ін. Гігієнічним вимогам до друкованих видань для молодших школярів із порушеннями зору присвячене методичне видання авторського колективу: С. Синьова, С. Федоренко, К. Глушенко, Г. Серпутько. Проте, на сучасному етапі розвитку освіти проблеми підручникотворення для осіб із порушеннями зору потребують більш докладного вивчення, що дозволить охопити не лише категорію здобувачів загальної середньої освіти, але й висвітлити проблеми створення, адаптації та видання підручників для здобувачів вищої освіти, які мають порушення зору.

Парадигма підручникотворення для здобувачів освіти 3 порушеннями зору $є$ досить розгалуженою. Тому термінологічним утворенням "Підручникотворення для здобувачів освіти 3 порушеннями зору" ми послуговуємося у широкому значенні, а саме: це і власне створення оригінального підручника з урахуванням специфічних вимог, i специфіка його адаптації та видання, 3 урахуванням можливостей сприймання здобувачів освіти з порушеннями зору.

Видання підручників рельєфно-крапковим шрифтом Л. Брайля та збільшеним шрифтом для закладів загальної середньої освіти в Україні забезпечується державою за бюджетні кошти на конкурсних (тендерних) засадах. Проте, на сьогодні сфера підручникотворення для здобувачів освіти із порушеннями зору потребує унормування, стандартизації конкретних вимог щодо підготовки, адаптації та видання підручників для осіб із порушеннями зору. I хоча забезпечення школярів із порушеннями зору підручниками і навчальними посібниками у спеціальних форматах в Україні здійснюється за державної підтримки, проте, все ще залишається складною проблемою, особливо в частині задоволення потреб учнів із порушеннями зору, які здобувають загальну середню освіту в закладах з інклюзивною формою навчання. Тоді як студенти із порушеннями зору, які продовжують здобувати освіту в закладах вищої освіти (ЗВО) України, практично позбавлені можливості користуватися підручниками i навчальними посібниками, необхідною словниководовідниковою літературою у спеціальних форматах, зокрема, надрукованою шрифтом Брайля. Жодної державної підтримки такі видання не мають, тому питання забезпечення підручниками i навчальними матеріалами у доступних форматах цілковито перекладається на заклади вищої освіти (3ВО), а чіткого механізму такого забезпечення також не існує. Доступними для незрячих можуть бути підручники, навчальнометодичні посібники та наукові видання в електронних неграфічних форматах, які за допомогою програм екранного доступу (спеціальні скрінрідери) студенти із глибокими порушеннями зору можуть читати, 
сприймаючи інформацію на слух через вивід мовлення, готуватися до різних видів занять, виконувати різноманітні завдання, готувати наукові кваліфікаційні роботи тощо. Проте не всі електронні документи є на сьогодні доступними для навчання таких студентів. Значна частина 3 них виконана у графічних, наприклад PDF-форматах, які некоректно, або й взагалі не розпізнаються скрінрідерами, особливо глибоко це відчутно за умов широкого залучення технологій дистанційного навчання. До доступних форматів умовно можна віднести й озвучену освітню літературу, тобто записану на різних носіях з голосу, проте, справа в тім, що не кожен підручник i далеко не 3 кожного предмета може сприйматися лише на слух студентом із порушеннями зору. Провідним серед доступних форматів для незрячих студентів залишаються книги, надруковані рельєфно-крапковим шрифтом Брайля. Однак видання такої літератури є чи не найдорожчим, тому українські заклади освіти майже не послуговуються ними у підготовці студентів з порушеннями зору. Хоча, під час сприймання лише на слух низки навіть гуманітарних дисциплін, у незрячих студентів можуть виникати вагомі труднощі 3 опануванням фахово важливих курсів, виконанням необхідних завдань тощо [1, с. 341], що може призводити навіть до низки психологопедагогічних проблем: невпевненості у власних силах, небажання (відмови) виконувати завдання, зневіри, розчарування, формування у студента маніпулятивної позиції, як наслідок: зниження академічної успішності тощо.

Питаннями соціально-психологічної адаптації студентів 3 порушеннями зору до умов навчання у ЗВО займалася Т. Гребенюк, деякі аспекти наступності у здобутті середньої та вищої освіти особами 3 порушеннями зору досліджувала С. Федоренко, питання створення умов доступності для якісного навчання незрячих студентів висвітлювалися у працях С. Федоренко, М. Федоренка, Г. Серпутько, Т. Гребенюк та ін.

3 огляду на розмаїтість форматів, специфіку видань навчальної літератури, відповідно до можливостей здобувачів освіти 3 порушеннями зору, вирішення проблем підручникотворення для осіб із порушеннями зору потребує формулювання базового теоретикометодичного підгрунтя задля пошуку більш ефективних шляхів забезпечення підручниками i навчальними посібниками здобувачів освіти з порушеннями зору як у сфері загальної середньої (спеціальної або інклюзивної), так і вищої освіти.

Залучення комплексного підходу дозволить, на нашу думку, багатоаспектно вирішити проблеми підручникотворення для осіб iз порушеннями зору: у дидактико-методичному, психолого- 
педагогічному та видавничо-поліграфічному аспектах. Проте, необхідним для цього $є$ наукове вирішення таких основних завдань:

1) вивчення проблем підручникотворення у загальній і спеціальній психолого-педагогічній літературі та практиці викладання;

2) аналіз нормативно-правової бази з проблем підготовки та видання навчальної літератури, зокрема для осіб із порушеннями зору, як в Україні, так і в країнах ЄC;

3) порівняльний наліз друкованих засобів навчання для здобувачів освіти з порушеннями зору;

4) формування методичних рекомендацій з підготовки, адаптації та видання підручників для здобувачів освіти 3 порушеннями зору з метою унормування та стандартизації вимог до підручникотворення для здобувачів освіти з порушеннями зору;

5) визначення механізмів та прикладних аспектів підручникотворення для здобувачів вищої освіти з порушеннями зору;

6) підготовка рекомендацій для викладачів закладів вищої освіти 3 використання підручників та організації навчальної й науководослідницької діяльності здобувачів вищої освіти з порушеннями зору.

Розв'язання основних завдань за окресленими вище напрямами дозволить, на нашу думку, налагодити видання та забезпечення якісними підручниками як осіб із порушеннями зору, які здобувають загальну середню, так і вищу освіту в Україні, що, в свою чергу, сприятиме й підвищенню якості здобуття освіти особами з порушеннями зору та створенню для них рівних 3 іншими здобувачами освіти умов навчання.

\section{Література:}

1. Серпутько Г.П. Забезпечення інформаційної доступності у здобутті якісної вищої гуманітарної освіти студентами із глибокими порушеннями зору : Матеріали Міжнародної науково-практичної конференції "Українська освіта: аксіологія європейського вибору", 21-22 жовтня 2021 року. м. Київ : Вид-во НПУ імені М.П. Драгоманова. C. 339-346. URL: http://evdisd.info/uk/materials/article/366/ 